\title{
Response to natural and simulated browsing of two Mediterranean oaks with contrasting leaf habit after a wildfire
}

\author{
Josep Maria EsPelta*, Abdessamad Habrouk, Javier RetanA \\ Centre de Recerca Ecològica i Aplicacions Forestals (CREAF) i Unitat d'Ecologia, Universitat Autònoma de Barcelona, \\ 08193 Bellaterra (Barcelona), Spain
}

(Received 31 May 2005; accepted 14 December 2005)

\begin{abstract}
In this study, we explore the response to browsing of two co-occurring Mediterranean oaks, the evergreen Quercus ilex and the deciduous Quercus cerrioides, resprouting in areas affected by large wildfires in central Catalonia (NE Spain). We tested three hypotheses: (i) differences in the preference of browsers will cause a higher impact of browsing on the deciduous oak, (ii) the deciduous oak will show a lower response to browsing than the evergreen one, and (iii) the response to browsing of $Q$. ilex and $Q$. cerrioides will differ depending on the season of the year when browsing occurs. To test the first hypothesis, we undertook the monitoring of the degree of browsing on resprouting evergreen and deciduous oaks after fire, while the second and third hypothesis were tested by mean of an experiment with different intensities of simulated browsing in different seasons of the year. The results indicate that $Q$. cerrioides individuals were more heavily browsed than $Q$. ilex ones. Moreover, browsing matched the two species in most of the size variables considered, cancelling the advantage in height and crown projection of the deciduous oak at the beginning of the resprouting process. In the experiment of simulated browsing, $Q$. ilex and $Q$. cerrioides showed a similar response to the different intensities of simulated browsing applied, but differences between species occurred depending on the season of the year when browsing occurred: $Q$. ilex showed a higher growth rate of crown projection than $Q$. cerrioides when it was browsed in autumn and winter, while the opposite pattern was obtained when stumps browsing occurred in spring and summer.
\end{abstract}

deciduous / evergreen / post-fire regeneration / Quercus ilex / Quercus cerrioides / succession

Résumé - Réponse à l'abroutissement après un incendie de forêt de deux chênes méditerranéens à feuillages contrastés. Dans cette étude, on a exploré la réponse de deux chênes méditerranéens, se rencontrant ensemble, Quercus ilex sempervirent et Quercus cerrioides caducifolié, rejetant dans de grandes zones affectées par des incendies de forêt dans le centre de la Catalogne. On a testé trois hypothèses : (i) des différences de préférence des animaux broutants causeront un impact très important sur le chêne caducifolié, (ii) le chêne caducifolié montrera une plus faible réponse à l'abroutissement que le chêne sempervirent, et (iii) les réponses à l'abroutissement de Quercus ilex et Quercus cerrioides diffèreront en relation avec la saison pendant laquelle l'abroutissement se produit. Pour tester la première hypothèse, nous avons entrepris de suivre le degré d'abroutissement sur les chênes sempervirents et les chênes caducifoliés rejetant après incendie, tandis que la deuxième et la troisième hypothèse étaient testées au moyen d'une expérimentation avec différents niveaux d'un abroutissement simulé pendant différentes saisons de l'année. Les résultats indiquent que Quercus cerrioides était plus fortement abrouti que Quercus ilex. D'ailleurs, l'abroutissement a assorti les deux espèces dans la plupart des variables de dimensions considérées, annulant les avantages de hauteur et de projection des couronnes du chêne caducifolié au début du processus de rejet. Dans l'expérimentation d'abroutissement simulé Quercus ilex et Quercus cerrioides ont montré une réponse similaire aux différentes intensités d'abroutissement simulées appliquées, mais des différences entre espèces se sont produites en relation avec la saison où a été appliqué l'abroutissement : Quercus ilex a montré un plus fort taux de croissance de la projection des couronnes que Quercus cerrioides lorsqu'il a été abrouti en automne et hiver, tandis que le modèle opposé a été obtenu quand l'abroutissement des souches intervenait au printemps et en été.

caducifolié / sempervirent / régénération après incendie / Quercus ilex / Quercus cerrioides / succession

\section{INTRODUCTION}

The response of Mediterranean-type ecosystems to fire has been extensively studied, especially in the Mediterranean Basin $[33,44]$. Despite a long history of interaction of different disturbance sources (e.g. wildfires, forest coppicing, overbrowsing), less attention has been paid to the consequences of secondary disturbances, such as the impact of browsing, on post-fire succession in these communities. The effect of fire on populations of Mediterranean species has been reported to be usually moderate, because plants have life-history traits that allow a very effective post-fire recovery, either by resprouting from fire-resistant structures or by germination of fire-

\footnotetext{
*Corresponding author: javier.retana@uab.es
}

protected seeds ([15, 27], but see [41]). However, resilience of Mediterranean communities after a wildfire may be constrained by the impact of herbivores, which may lengthen the time required for the vegetation to return to the pre-fire conditions or even divert this return [38].

Resprouting after fire has been viewed as an efficient lifehistory trait by which woody plants can recover lost biomass after disturbance $[2,36]$. However, resprouting involves a large mobilization and consumption of below-ground reserves [8]. Therefore, it has been argued that repeated browsing on resprouting individuals may further deplete below-ground reserves and compromise the success of the regeneration process $[9,45]$. The impact of browsing in the community of resprouting plants may be expected to vary depending on the 
interaction among: (i) preferences of the herbivores, (ii) season of browsing and (iii) differences in life history traits among the plant species affected. One of the plant traits that may be expected to determine specific differences in the extent of browsing is the leaf habit (evergreen vs. deciduous). On the one hand, the preference of herbivores for deciduous species instead of con-generic sclerophyllous-evergreens [21, 29] has been often suggested because of differences between these species in leaf texture and thickness, nitrogen content, indigestible substances (cutin, lignin) and secondary compounds (e.g. tannins [42], but see [22]). Moreover, distinct seasonal patterns of renewal of leaves in deciduous and evergreen species involve differences in carbon and nutrient allocation in the plant that may have important implications, depending on the season of browsing, both for palatability and vulnerability to herbivores [7, 28]. Finally, it has been frequently presumed that evergreen species would be more resilient to repeated disturbances because their lower resource-loss ratios [1] would allow them to be better adapted to harsh environments (e.g., high water stress, temperature and light intensity) occurring in repeatedly disturbed sites ([32,37], but see [5]). Taking into account the abovementioned differences, some authors have suggested the idea that the greater dominance of evergreen oaks in the Mediterranean Basin in comparison to deciduous ones has been partially favored by occurrence of repeated disturbances, including the impact of domestic herbivores [12]. However, we do not know at present any study specifically aimed to test whether deciduous and evergreen oaks resprouting after fire differ in their sensitivity to browsing and to test whether differences between these species depend on the season when browsing occurs.

In this study, we explore the response to browsing of two co-occurring Mediterranean oak species resprouting after a wildfire in central Catalonia (NE Spain), the evergreen $Q$. ilex L. and the deciduous $Q$. cerrioides Willk. et Costa. Quercus ilex is a widespread species, present over a large area extending $6000 \mathrm{~km}$ longitudinally from Portugal to Syria and $1500 \mathrm{~km}$ latitudinally from Morocco and Algeria to France [43], whereas the distribution of $Q$. cerrioides - a species from the Quercus humilis group with several probable introgressions from other deciduous Quercus - is also abundant in the NE Iberian Peninsula [10]. In this study we have tested three hypotheses. The first one is that the deciduous oak will be more affected by browsing than the evergreen one, because browsers prefer deciduous than evergreen species [21, 29]. To test this hypothesis, we have undertaken the monitoring of the degree of browsing on resprouting evergreen and deciduous oaks after fire. The second hypothesis refers to the response to browsing (how plants respond to, and are able to compensate for browsing). We hypothesize that this response will be larger in the evergreen than in the deciduous species due to differences in sprouting ability (number of resprouts) after recurrent disturbances [17] and because the lower resource-loss ratios of the evergreen species allows them to better overcome the critical conditions during post-disturbance regeneration [32]. The third hypothesis predicts that the response to browsing of $Q$. ilex and $Q$. cerrioides will differ depending on the season of the year when browsing occurs [6]. The two oaks studied differ in the phenology of leaf production: $Q$. cerrioides mostly renews its foliar tissues in early spring (i.e. April), while partial renewal of leaves and shoots of $Q$. ilex stars later, in MayJune, although a second flush of shot growth and leaves for this species is usually produced in early autumn [14]. Thus, we expect that the negative effects of browsing will be higher in early spring for the deciduous than for the evergreen species, because the former renews completely its foliar tissues in that season. To test the second and third hypotheses, we have carried out an experiment with different intensities of simulated browsing on the two species in different seasons of the year.

\section{MATERIALS AND METHODS}

\subsection{Study area}

This study was carried out in the regions of Bages and Berguedà (Catalonia, NE Spain; $41^{\circ} 45^{\prime}$ to $42^{\circ} 6^{\prime} \mathrm{N} ; 1^{\circ} 38^{\prime}$ to $2^{\circ} 1^{\prime} \mathrm{E}$; 350 to $950 \mathrm{~m}$ above sea level). Climatic conditions vary from dry-subhumid to subhumid Mediterranean (according to the Thornwaite index), with mean annual temperature of $10-13{ }^{\circ} \mathrm{C}$ and mean annual precipitation of 550-700 mm. This area was affected in July 1994 by the largest wildfire historically recorded in Catalonia. The fire burned 24322 ha, of which $71 \%$ was forested. According to the data provided by the Forest Ecological Inventory of Catalonia [24], the main forest tree species before the fire was Pinus nigra $(75 \%)$ while $Q$. ilex and $Q$. cerrioides were very common in the understory of these pine forests. Due to the nil regeneration of $P$. nigra after the fire, forests changed to woodlands dominated by resprouted $Q$. ilex and $Q$. cerrioides stumps [16]. These two Quercus species resprout vigorously after disturbances [5,30,31], with sprouts occurring by activation of dormant buds located at the stump level, the root-crown or to a lesser extent on roots $[19,39]$. Quercus cerrioides shows a more rapid foliage recovery than $Q$. ilex [5], probably because growth in $Q$. ilex could be constrained by a higher investment in longer lasting, sclerophyllous leaves [1].

The large extent of the burned area and the need to replace the traditional exploitation of wood in the pine forests, have promoted extensive land use changes involving the conversion of 2365 ha of post-fire woodlands (9.7\% of the total burned area) to rangelands [16]. In these areas, domestic cattle, mainly cows, eat grasses and resprouting Quercus stumps. Cows mainly prefer grasses from late winter to early summer, and eat foliage, shoots and acorns of oaks in summer and autumn [20]. We have carried out two different studies in these rangelands to assess the effect of post-fire natural and simulated browsing on $Q$. ilex and $Q$. cerrioides resprouting stumps. These observations and experiments were carried out in different locations within the burned area (Fig. 1).

\subsection{Degree of browsing on the two species}

This study was carried out in three sites, Socarrada, Alzina Grossa and Cal Teixidor (Fig. 1), in 1998, i.e., 4 years after the fire. In each site, an area intensively browsed by cows since the first year after fire was chosen, together with a nearby enclosure area protected from cow browsing throughout this time. Browsing was estimated as extensive (following $[21,47]$ ) because of the consumption of many tips and 


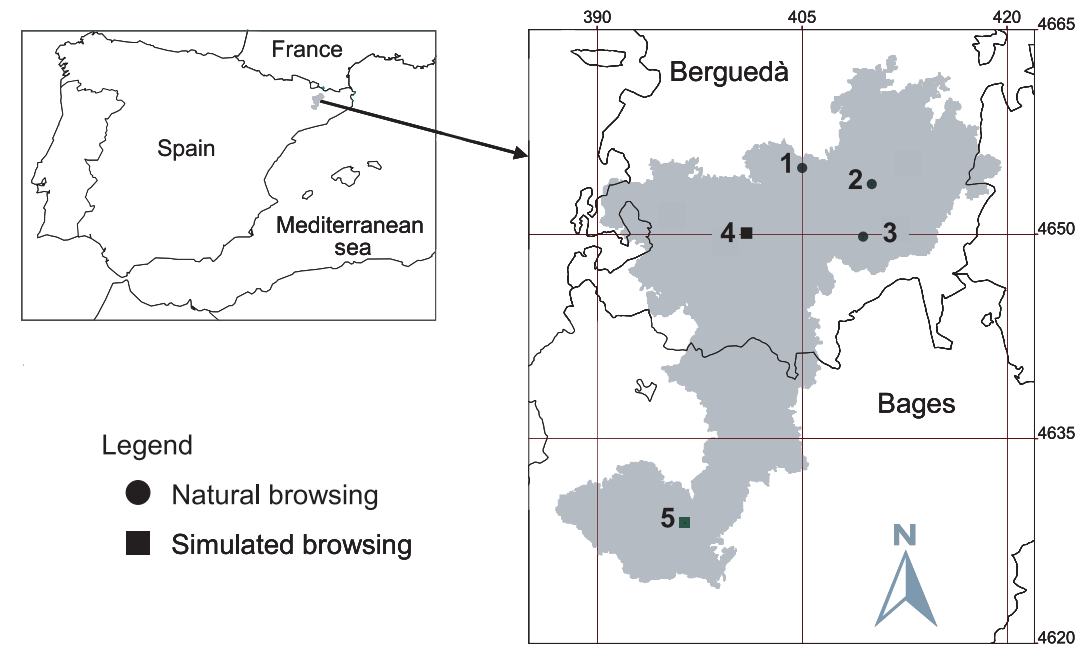

Figure 1. Geographical location of the sites sampled in this study along the area of Bages and Berguedà regions affected by the large wildfire of 1994 (shaded). Study sites: 1, Socarrada; 2, Alzina Grossa; 3, Cal Teixidor; 4, Cal Barraler; 5, L'Obaga d'Antius. leaves of $Q$. ilex and $Q$. cerrioides stumps and the heavy consumption of less palatable plants (e.g. Rosmarinus officinalis, Cistus ssp.) present in the area. Fifteen browsed stumps and fifteen control (unbrowsed) stumps of $Q$. ilex and $Q$. cerrioides were sampled in each site. Stump surface was used as a measure of the size of the individual before sprouting, and no initial differences in this variable were found among sites or species before browsing (two-way ANOVA, $p>0.09$ in all cases).

We determined browsing preference by using a categorical classification of the impact of cows on resprouting stumps of the two species in the area intensively browsed of each site. The following categories were identified: 0 , unbrowsed; 1 , few shoot tips browsed; 2 , most shoot tips browsed; 3 , few shoots of the previous year browsed; 4, most shoots of the previous year browsed; 5 , completely browsed and defoliated. We have compared the number of individuals of each species in each browsing category with a $\chi^{2}$ test. The three sites have been analyzed separately.

We have also measured the following variables from each stump: survival, number of resprouts, total height and crown projection (measuring two perpendicular diameters of the crown and computing the projection as an ellipse). The effects of site, species and treatment (browsed, not browsed) on these variables were analyzed by ANOVA. All variables except the number of resprouts were normalized by a log transformation. The sequential Bonferroni method was employed to control the group-wide type I error rate [40], considering together all statistical tests of this study. The Fisher's protected least significant difference post-hoc test was used to analyze differences among levels of each main factor.

\subsection{Response of the two species to different intensities and seasons of simulated browsing}

This experiment started in winter 1998, i.e. 4 years after the fire, in two areas that had been totally excluded from browsing during the first years after the fire: L'Obaga d'Antius and Cal Barraler (Fig. 1). In each site, two 0.25 ha plots were established. At the beginning of the experiment, 96 Q. ilex and 96 Q. cerrioides individuals were randomly chosen and numbered in each plot. These tagged individuals were randomly assigned to one of the three treatments with different intensity of simulated browsing. The treatments simulated brows- ing by cows by randomly clipping a certain proportion of all annual shoots from the previous season: $0 \%$ (control, stumps were left untouched), 25\% (low-intensity browsing) and 50\% (higher-intensity browsing). This experimental procedure was repeated with different individuals at the beginning of each season: summer (June), autumn (September), winter (late November) and spring (April). For each combination of species, treatment and season, there were 8 sampling individuals per plot.

The experiment lasted one year, i.e., individuals clipped in each season were sampled again one year later, that is, in spring, summer, autumn and winter of the following year. In each individual, the following variables were measured at the beginning and at the end of the experiment: total number of resprouts larger than one $\mathrm{cm}$ of basal diameter, height and crown projection of the individual. Three resprouts per individual were marked at the beginning of the experiment and were also monitored one year later to determine mean annual shoot growth per individual. Relative growth rate (RGR) of number of resprouts, height and crown projection was calculated as RGR $=(\mathrm{ln}$ $\left.\left(\mathrm{X}_{i}-\mathrm{X}_{i-1}\right) / \mathrm{X}_{i-1}\right)$, where $\mathrm{X}_{i}$ was the value of the variable at the end of the experiment, and $X_{i-1}$ was its value at the beginning.

The effects of species ( $Q$. ilex, $Q$. cerrioides), the simulated browsing treatment $(0 \%, 25 \%, 50 \%$ browsing), season (winter, spring, summer, autumn), site and plot (nested within site) on these variables were analyzed by ANOVA's. In all cases, inspection of residuals was carried out to check for normality and homoscedasticity. Data of crown projection were normalized by a log transformation. The sequential Bonferroni method was employed considering all ANOVA tests together to control the group-wide type I error rate [40]. The Fisher PLSD post-hoc test was used to compare the different levels of each variable.

At the start of the study, there were significant differences between the two species in the number of resprouts (ANOVA, $\mathrm{F}_{1,714}=93.8$, $p<0.0001)$ and height $\left(\mathrm{F}_{1,714}=19.7, p<0.0001\right)$ but not in stump surface $(p>0.20)$ or crown projection $(p>0.35)$. Quercus ilex had more resprouts per stump than $Q$. cerrioides (respectively, $7.0 \pm 0.3$ vs. $4.1 \pm 0.14$ ) but $Q$. ilex individuals attained a lower height (respectively, $157 \pm 2 \mathrm{~cm}$ vs. $171 \pm 3 \mathrm{~cm}$ ). No differences in these morphological variables existed between sites, and individuals assigned to the different browsing treatments or browsing seasons $(p>0.10$ in all cases). 
Table I. Browsing intensity by cows on resprouting stumps of $Q$. ilex and $Q$. cerrioides in the area intensively browsed of the three sites used to analyze the sensitivity of the two species to browsing. The following browsing categories were identified: 1, few shoot tips browsed; 2, most shoot tips browsed; 3 , few shoots of the previous year browsed; 4, most shoots of the previous year browsed; 5 , completely browsed and defoliated. $N=15$ individuals per species and site.

\begin{tabular}{lccccc}
\hline & \multicolumn{5}{c}{ Browsing intensity } \\
\hline Species & 1 & 2 & 3 & 4 & 5 \\
\hline (a) Cal Teixidor & 0 & 0 & 46.7 & 46.7 & 6.6 \\
Quercus cerrioides & 13.3 & 60.0 & 13.3 & 13.3 & 0 \\
Quercus ilex & 0 & 0 & 26.7 & 73.3 & 0 \\
\hline (b) Alzina Grossa & 6.7 & 33.3 & 60.0 & 0 & 0 \\
Quercus cerrioides & \multicolumn{1}{c}{0} & & & \\
Quercus ilex & 0 & 0 & 13.3 & 53.3 & 33.3 \\
\hline (c) Socarrada & 40.0 & 20.0 & 33.3 & 6.6 & 0 \\
Quercus cerrioides & \multicolumn{7}{c}{}
\end{tabular}

\section{RESULTS}

\subsection{Intensity of browsing on the two species}

Most $Q$. cerrioides individuals present in the browsing area were heavily browsed, while $Q$. ilex individuals were subjected to considerably lower degree of browsing (Tab. I). Differences between species were significant in the three sites $\left(\chi^{2}=17.4,19.0\right.$ and 22.4 in Cal Teixidor, Alzina Grossa and Socarrada, $p<0.001$ in the three cases). Despite the different levels of browsing intensity recorded we did not observe stump mortality of either Quercus species.

None of the factors or their interactions affected the number of resprouts per stool (Tab. II). There was a significant effect of species and a very important effect of browsing in total height and crown projection (Tab. II). These variables attained higher values in $Q$. cerrioides than in $Q$. ilex stools and in control than in browsed stools. However, there was an interaction between both factors, so there were differences between species in the control treatment, but not in the browsed one (Fig. 2). The effect of site was not significant, while the interaction between site and browsing treatment was only lightly significant for total height.

\subsection{Response of the two species to different intensities and seasons of simulated browsing}

None of the levels of simulated browsing led to stump mortality of either Quercus species. Intensity of browsing did not affect the number of resprouts or the height attained by individuals, but it had a significant effect in their crown projection (Tab. III). Control stumps showed a lower relative growth rate in crown projection than those in the two browsing treatments (control: $0.00 \pm 0.04$; low-intensity browsing: $0.14 \pm$ 0.3 ; high-intensity browsing: $0.22 \pm 0.05$ ). Both RGR in crown
Table II. F values from ANOVA tests of effects of species ( $Q$. ilex, $Q$. cerrioides), site and browsing treatment on different morphological variables of sprouting stools in the study of the sensitivity of the two species to browsing. Significant coefficients (at $\alpha=0.05$ when the sequential Bonferroni method is employed) are indicated in bold. All variables except number of stems were log-transformed.

\begin{tabular}{lcccc}
\hline Source & df & $\begin{array}{c}\text { Number } \\
\text { of resprouts }\end{array}$ & $\begin{array}{c}\text { Total } \\
\text { height }\end{array}$ & $\begin{array}{c}\text { Crown } \\
\text { projection }\end{array}$ \\
\hline Species (SP) & 1 & 0.4 & $\mathbf{2 0 . 0}$ & $\mathbf{8 . 4}$ \\
Browsing treatment (B) & 1 & 4.2 & $\mathbf{1 3 8 . 1}$ & $\mathbf{9 1 . 1}$ \\
Site $($ S) & 2 & 0.9 & 0.1 & 0.6 \\
SP $\times$ B & 1 & 0.0 & $\mathbf{8 . 7}$ & $\mathbf{1 9 . 6}$ \\
SP $\times$ S & 2 & 0.4 & 2.3 & 1.9 \\
B $\times$ S & 2 & 1.0 & $\mathbf{8 . 0}$ & 0.5 \\
SP $\times$ B $\times$ S & 2 & 1.0 & 0.3 & 1.9 \\
Residual & 169 & & & \\
\hline
\end{tabular}
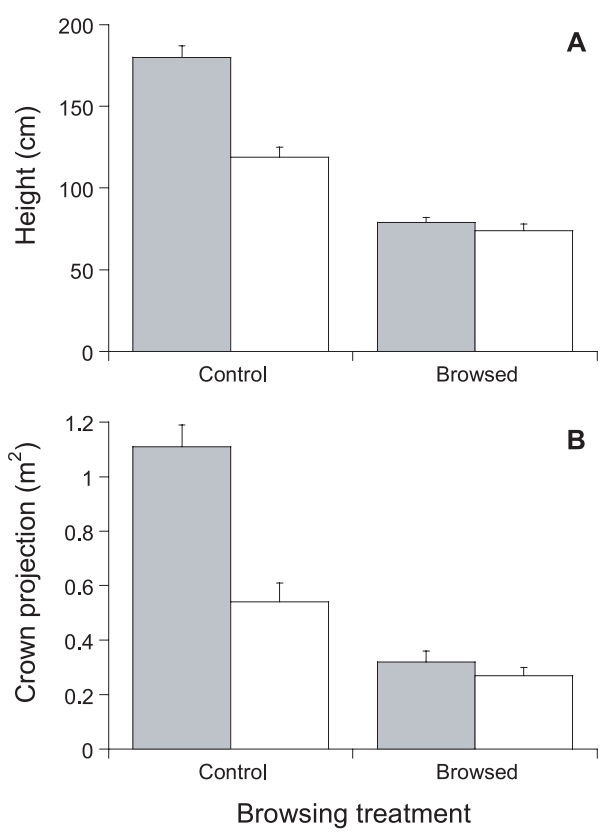

Figure 2. Total height $(\mathrm{A}$, in $\mathrm{cm})$ and crown projection $\left(\mathrm{B}\right.$, in $\left.\mathrm{m}^{2}\right)$ of sprouting $Q$. cerrioides (solid bars) and $Q$. ilex stumps (open bars) in control and in browsed plots in the study of the sensitivity of the two species to browsing. Vertical bars extend over $+1 \mathrm{SE}$ of the mean.

projection and height varied according to the season when simulated browsing was applied (Tab. III). In both cases, stumps browsed at the beginning of the winter period showed lower relative growth rate than stumps browsed in the other periods of the year, and even did not recover in the case of crown projection (Fig. 3). Concerning the comparison between $Q$. ilex and $Q$. cerrioides, RGR of number of resprouts and height did not differ according to species (Tab. III). Thus, differences observed at the beginning of the experiment persisted at the end of the study, in spite of the treatment of intensity of browsing or season. Quercus ilex individuals maintained more resprouts per stump than $Q$. cerrioides (respectively, $7.5 \pm 0.3$ resprouts per stump vs. $4.1 \pm 0.1$ resprouts per stump), while 
Table III. F values from ANOVA tests of effects of species ( $Q$. ilex, $Q$. cerrioides), browsing treatment (not browsed, low- intensity and high-intensity browsing), season of the year (winter, spring, summer and autumn), site and plot (nested within site) on the relative growth rate in number of resprouts, height and crown projection in the experiment of simulated browsing. Significant coefficients (at $\alpha=0.05$ after applying the sequential Bonferroni method) are indicated in bold.

\begin{tabular}{lcccc}
\hline Source & df & $\begin{array}{c}\text { RGR number } \\
\text { of resprouts }\end{array}$ & $\begin{array}{c}\text { RGR total } \\
\text { height }\end{array}$ & $\begin{array}{c}\text { RGR crown } \\
\text { projection }\end{array}$ \\
\hline Browsing (B) & 2 & 1.5 & 0.3 & $\mathbf{1 1 . 4}$ \\
Species (Sp) & 1 & 0.2 & 3.7 & 0.1 \\
Season (Se) & 3 & 2.7 & $\mathbf{6 . 6}$ & $\mathbf{6 0 . 4}$ \\
Site (S) & 1 & $\mathbf{7 . 8}$ & 1.2 & 0.6 \\
Plot (Site) & 2 & 0.3 & 4.0 & $\mathbf{1 4 . 1}$ \\
$\mathrm{B} \times \mathrm{Sp}$ & 6 & 1.1 & 0.6 & 0.4 \\
$\mathrm{~B} \times \mathrm{Se}$ & 6 & 1.8 & 1.2 & 3.5 \\
$\mathrm{~B} \times \mathrm{S}$ & 2 & 1.9 & 0.1 & 0.2 \\
$\mathrm{Sp} \times \mathrm{Se}$ & 3 & 0.3 & 1.6 & $\mathbf{7 . 6}$ \\
$\mathrm{Sp} \times \mathrm{S}$ & 1 & 0.1 & 0.1 & 0.2 \\
$\mathrm{Se} \times \mathrm{S}$ & 3 & 0.2 & 0.1 & $\mathbf{1 4 . 6}$ \\
$\mathrm{B} \times \mathrm{Sp} \times \mathrm{Se}$ & 6 & 0.8 & 0.6 & 0.9 \\
$\mathrm{~B} \times \mathrm{Sp} \times \mathrm{S}$ & 2 & 0.3 & 1.4 & 0.6 \\
$\mathrm{~B} \times \mathrm{Se} \times \mathrm{S}$ & 6 & 0.1 & 1.0 & 1.0 \\
$\mathrm{Sp} \times \mathrm{Se} \times \mathrm{S}$ & 3 & 1.3 & 0.2 & 3.7 \\
$\mathrm{~B} \times \mathrm{Sp} \times \mathrm{Se} \times \mathrm{S}$ & 6 & 1.2 & 0.1 & 1.0 \\
$\mathrm{Re}$ sidual & 714 & & & \\
\hline
\end{tabular}

Q. cerrioides had a higher height than $Q$. ilex $(167 \pm 2 \mathrm{~cm}$ vs. $186 \pm 3 \mathrm{~cm})$. The interaction of species and season of browsing was only significant for the relative growth rate of crown projection (Tab. III). Thus, $Q$. ilex showed a higher growth rate of crown projection than $Q$. cerrioides when browsed in autumn and winter (especially in winter, when none of the species recovered after browsing), while the opposite was obtained when stumps were browsed in spring and summer (Fig. 4). Few differences were obtained between the sites where the experimental treatments were applied (Tab. III): the highest growth rate in number of resprouts was observed in Cal Barraler, while the highest growth rate in crown projection was obtained in Cal Barraler in summer, autumn and winter, but in spring in L'Obaga d'Antius (data not shown).

\section{DISCUSSION}

Neither the effect of natural browsing, nor the different levels and seasons of simulated browsing, led to stump mortality of either Quercus species, even though browsing was carried out on individuals just recovering from a recent severe disturbance event (i.e. fire). These results support previous findings on the role of repeated disturbances in other Mediterranean resprouting species which have pointed out the occurrence of major architectural and physiological changes (e.g. resprout number, height, nutrient content, photosynthesis rates), but few mortality effects (see among others, $[8,13,35,46])$. Resprouters show high resilience to repeated disturbances and it is difficult to observe mortality processes due to the exhaus-
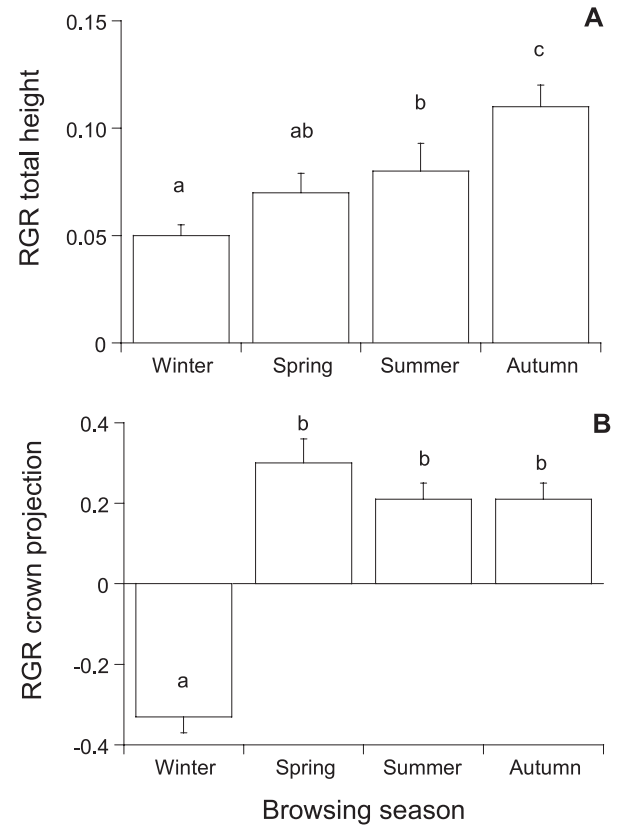

Figure 3. Relative growth rate of (A) total height and (B) crown projection of stumps browsed in the different seasons of the year in the experiment of simulated browsing. Vertical bars extend over $+1 \mathrm{SE}$ of the mean. Different letters indicate significant differences among periods according to the Fisher PSLD post-hoc test.

tion of belowground reserves after repeated disturbances [9]. In our case, of course, it should be taken into account that the time interval when individuals suffered browsing (four years) is short compared to the expected longevity of oaks.

Although browsing did not cause mortality in either of the two species of oaks analyzed, in our study, as has been described for other Quercus species [23,34], the negative effects of browsing were evident: the results of browsing on plants of the two species support our first hypothesis of a preferential browsing on the deciduous oak in comparison to the evergreen one. Most $Q$. cerrioides individuals in the browsing area of each site were heavily browsed, while $Q$. ilex individuals were subjected to considerably lower degree of browsing. Moreover, browsing matched the two species in most of the size variables considered, canceling the initial advantage in height and crown projection exhibited by the deciduous oak. It remains unclear whether this preferential browsing of the deciduous oak is caused by the behavior of herbivores or by structural or chemical differences between species that reduce browsing intensity (i.e. lower nitrogen content and higher sclerophylly of leaves of evergreen oaks compared to deciduous ones; [7, 12,21,26,29]. Some authors have noted that domestic herbivores are less selective than wild ones, and they browse more of the larger ( $Q$. cerrioides in our study) or dominant plants $[25,48]$. The fact that stumps of the two species were browsed until they attained a similar size and shape seems to indicate that browsing activity proceeds until animals can not easily consume them, because the branching pattern of these resprouting stumps, with numerous and lignified resprouts, protects a fraction of the leaves from browsing. 


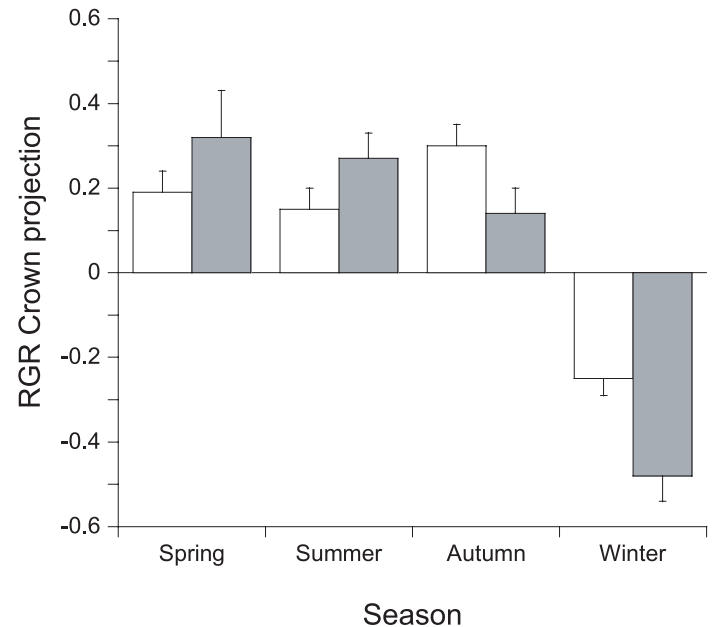

Figure 4. Relative growth rate of crown projection of $Q$. cerrioides (solid bars) and $Q$. ilex stumps (open bars) browsed in the different seasons of the year in the experiment of simulated browsing. Vertical bars extend over $+1 \mathrm{SE}$ of the mean.

Quercus ilex and $Q$. cerrioides responded similarly to the different intensities of simulated browsing applied. Therefore, our second hypothesis that predicted a lower response of the deciduous species was not supported by these observations. Previous studies comparing the resprouting patterns of deciduous and evergreen Mediterranean oaks have shown that the evergreen $Q$. ilex is able to produce more resprouts than the deciduous $Q$. cerrioides after disturbances [5, 17], but resprouts of the later species exhibit higher height growth and leafiness $[5,17]$. Therefore, these two opposite traits in the resprouting process could lead to a final similar response to our simulated browsing experiment. As suggested by Bonfil et al. [5] the ability of $Q$. ilex to produce a higher number of resprouts will only turn advantageous when it is confronted with highly reiterated and intense disturbances, probably a much more severe regime than the one we applied in our experiment. The effect of the browsing season on the final size of individuals was relatively small, but there were differences in the relative growth rates in height and crown projection among seasons (Fig. 3), with individuals of both species browsed at the beginning of winter reaching lower crown projection at the end of the study. This negative impact of browsing just at the onset of the non-vegetative period could be caused by the massive destruction of newly formed buds that imply a loss of photosynthetic tissues for the next growing period. Concerning the third hypothesis, which was that the effects of browsing would be different in both species depending on the browsing season because they differ in the phenology of leaf production [3,4], only few differences appeared in crown projection between species in the different seasons, but these differences partially contradicted our initial ideas. Thus, $Q$. cerrioides showed a higher growth rate of crown projection than $Q$. ilex when it was browsed in spring and summer, while the later species obtained grew better when browsed in autumn or at the beginning of winter. This higher ability of $Q$. cerrioides to overcome simulated browsing in spring and early summer could be related to architectural differences between resprouts of the two species, leading to a higher growth in leafiness of $Q$. cerrioides in comparison with $Q$. ilex [5]. Conversely, the observed higher recovery of $Q$. ilex to simulated browsing during autumn could be related to the ability of this species to produce a new flush of shoot growth during this season, a pattern rarely observed in $Q$. cerrioides (J.M. Espelta, personal observation).

It has been hypothesized that a moderate disturbance regime could favor $Q$. cerrioides over $Q$. ilex, and even promote, in the long run, the withdrawal of the latter species in areas where they currently coexist $[5,18]$. Nevertheless, our comparison of the response of the two species to browsing indicates that, under browsing following post-fire recovery, the preferential browsing on $Q$. cerrioides stumps can turn the initial advantage of this species and, to some extent, promote the maintenance of mixed oak forests. These results stress the importance of analyzing possible differences among plant species to different disturbance types (i.e. fire may burn similarly deciduous and evergreen oaks in a stand but herbivores may browse them differently) rather than simple considering all disturbances identical. Thus, the coexistence of $Q$. ilex and $Q$. cerrioides in large areas of the Mediterranean region could be partially mediated by a different response of these species to different disturbances, such as fire and browsing. Notwithstanding this, differences between these groups in other traits, such as their reproductive outcome [11] or regeneration niche [18] might be also crucial to understand the present abundance and potential changes in the dominance of deciduous and evergreen Mediterranean oaks.

Acknowledgements: We are grateful to Consuelo Bonfil, Anselm Rodrigo and Montserrat Vilà for helpful comments on an early draft of the manuscript. This research was partly funded by INTERREG III (EU) project I3A-100-1-E and the Department of Environment (Generalitat de Catalunya).

\section{REFERENCES}

[1] Aerts R., The advantages of being evergreen, Trees 10 (1995) 402 407.

[2] Bellingham P.J., Sparrow A.D., Resprouting as a life history strategy in woody plant communities, Oikos 89 (2000) 409-416.

[3] Blondel J., Aronson J., Biology and wildlife of the Mediterranean region, Oxford University Press, Oxford, 1999.

[4] Blondel J., Dias P.C., Summergreenness, evergreenness and life history variation in Mediterranean blue tits, in: Arianoutsou M., Groves R.H. (Eds.), Plant-animal interactions in Mediterraneantype ecosystems, Kluwer Academic Publishers, Dordrecht, 1994, pp. 25-36.

[5] Bonfil C., Cortés P., Espelta J.M., Retana J., The role of disturbance in the co-existence of the evergreen Quercus ilex and the deciduous Quercus cerrioides, J. Veg. Sci. 15 (2004) 423-430.

[6] Briske D.D., Strategies of plant survival in grazed systems: a functional interpretation, in: Hodgson J., Llius A.W. (Eds.), The ecology and management of grazing systems, CAB International, Wallingford, 1996, pp. 37-67.

[7] Bryant J.P., Chapin F.S. III, Klein D.R., Carbon/nutrient balance of boreal plants in relation to vertebrate herbivory, Oikos 40 (1983) 357-368.

[8] Canadell J., Lloret F., López Soria L., Resprouting vigour of two Mediterranean shrub species after experimental fire treatments, Vegetatio 95 (1991) 119-126. 
[9] Canadell J., López-Soria L., Lignotuber reserves support regrowth following clipping of two Mediterranean shrubs, Funct. Ecol. 12 (1998) 31-38.

[10] Castroviejo S., Laínz M., López-González G., Montserrat P., Muñoz F., Paiva J., Villar L., Flora Ibérica: plantas vasculares de la Península Ibérica e Islas Baleares, Vol. II, PlatanaceaePlumbaginaceae, Real Jardín Botánico, CSIC, Madrid, 1990.

[11] Cortés P., Distribución y dinámica de un Quercus caducifolio (Q. cerrioides Willk. \& Costa) y uno perennifolio (Q. ilex L.) en Catalunya. Análisis de la ecología de la reproducción, la respuesta de las plántulas a factores ambientales y la respuesta a las perturbaciones, Ph. D. thesis, Universidad Autónoma de Barcelona, Barcelona, 2003.

[12] Cuartas P., García-González R., Quercus ilex browse utilization by Caprini in Sierra de Cazorla and Segura (Spain), Vegetatio, 99-100 (1992) 317-330.

[13] Damesin C., Rambal S., Joffre R., Co-occurrence of trees with different leaf habit: a functional approach on Mediterranean oaks, Acta Oecol. 19 (1998) 195-204.

[14] De Lillis M., Fontanella A., Comparative phenology and growth in different species of the Mediterranean maquis of central Italy, Vegetatio 99/100 (1992) 83-96.

[15] Delitti W., Ferran A., Trabaud L., Vallejo R.V., Effects of fire recurrence in Quercus coccifera L. shrublands of the Valencia Region (Spain), Plant Ecol. 177 (2005) 57-70.

[16] Espelta J.M., Rodrigo A., Habrouk A., Meghelli N., Ordoñez J.L., Retana J., Land use changes, natural regeneration patterns and restoration practices after a large wildfire in NE Spain: Challenges for fire ecology and landscape restoration, in: Trabaud L., Prodon R. (Eds.), Fire and Biological Processes, Backhuys Publishers, Leiden, 2002, pp. 315-324.

[17] Espelta J.M., Retana J., Habrouk A., Resprouting patterns after fire and response to stool cleaning of two coexisting Mediterranean oaks with contrasting leaf habits on two different sites, For. Ecol. Manage. 179 (2003) 401-414.

[18] Espelta J.M., Cortés P., Mangirón M., Retana J., Differences in biomass partitioning, leaf nitrogen content and water use efficiency $\left(\delta^{13} \mathrm{C}\right)$ result in a similar performance of seedlings of two Mediterranean oaks with contrasting leaf habit, Ecoscience, 12 (2005) 447-454.

[19] Espelta J.M., Sabaté S., Retana J., Resprouting dynamics, in: Rodà F., Retana J., Gracia C.A., Bellot J. (Eds.), Ecology of Mediterranean evergreen oak forests, Springer-Verlag, Berlin, 1999, pp. 61-73.

[20] Etienne M., Systèmes sylvopastoraux en région méditerranéenne française, INRA éditions, Avignon, 1995.

[21] Etienne M., Derzko M., Rigolot E., Browse impact in silvopastoral systems participating in fire prevention in the French Mediterranean region, in: Etienne M. (Ed.), Western European silvopastoral systems, INRA éditions, Versailles, 1996, pp. 93-102.

[22] Gallardo A., Merino J., Leaf decomposition in two Mediterranean ecosystems of southwest Spain: influence of substrate quality, Ecology 74 (1993) 152-161.

[23] Gómez-Gutiérrez J.M., Pérez-Fernández M., The "dehesas", silvopastoral systems in semiarid Mediterranean regions with poor soils, seasonal climate and extensive utilization, in: Etienne M. (Ed.), Western European silvopastoral systems, INRA éditions, Nancy, 1996, pp. 55-70.

[24] Gracia C., Burriel J.A., Ibáñez J.J., Mata T., Vayreda J., Inventari ecològic i forestal de Catalunya. Regió forestal IV, Centre de Recerca Ecològica i Aplicacions Forestals, Barcelona, 2000.

[25] Heuze P., Schnitzler A., Klein F. Consequences of increased deer browsing winter on silver fir and spruce regeneration in the Southern Vosges mountains: Implications for forest management, Ann. For. Sci. 62 (2005) 175-181.

[26] Joffre R., Rambal S., Functional attributes in Mediterranean-type ecosystems, in: Puignaire P.I., Valladares F. (Eds.), Handbook of Functional Plant Ecology, 1999, Marcel Dekker, New York, pp. 347-380.
[27] Keeley J.E., Zedler P., Reproduction of chaparral shrubs after fire: a comparison of sprouting and seedling strategies, Am. Midl. Nat. 99 (1978) 142-161.

[28] Kozlowski T.T., Effects of environmental stresses on deciduous trees, in: Mooney H.A. (Ed.), Response of plants to multiple stresses, Academic Press, New York, 1991, pp. 391-411.

[29] Leouffre M.C., Lecrivain E., Leclerc B., Consommation par des caprins de Quercus ilex et Quercus pubescens dans un taillis méditerranéen, XVIth Int. Grassland Congress, Nice, 1989, pp. 1983-1084.

[30] Lloret F., Siscart D., Los efectos demográficos de la sequía en poblaciones de encina, Cuadernos SECF 2 (1995) 77-81.

[31] López-Soria L., Castell C., Comparative genet survival after fire in woody Mediterranean species, Oecologia 91 (1992) 493-499.

[32] Mazzoleni S., Spada F., Deciduous broadleaved versus evergreen sclerophyllous forest. Disturbance and local shifting dominance in Mediterranean environments, in: Teller A., Mathy P., Jeffers J.N.R. (Eds.), Responses of forests ecosystems to environmental changes, Elsevier Science Publishers, Amsterdam, 1992, pp. 839-842.

[33] Naveh Z., The evolutionary significance of fire in the Mediterranean region, Vegetatio 29 (1975) 199-208.

[34] Papatheodorou E.F., Pantis J.D., Stamou G.P., The effect of grazing on phenology and biomass allocation in Quercus coccifera, Acta Oecol.19 (1998) 339-347.

[35] Pausas J.G., Resprouting of Quercus suber in NE Spain after fire, J. Veg. Sci. (1997) 703-706.

[36] Pausas J.G., Resprouting vs. seeding - a Mediterranean perspective, Oikos 94 (2001) 193-194.

[37] Quézel P., Médail F., Écologie et biogéographie des forêts du bassin méditerranéen, Elsevier SAS, Paris, 2003.

[38] Quinn R.D., Mammalian herbivory and resilience in Mediterranean climate ecosystems, in: Dell B., Hopkins A.J.M., Lamont B.B. (Eds.), Resilience in Mediterranean type ecosystems, Dr. W. Junk Publishers, Dordrecht, 1986, pp. 113-128.

[39] Retana J., Riba M., Castell C., Espelta J.M., Regeneration by sprouting of holm oak (Quercus ilex) stands exploited by selection thinning, Vegetatio 99-100 (1992) 355-364.

[40] Rice W.R., Analyzing tables of statistical tests, Evolution 43 (1989) 223-225.

[41] Rodrigo A., Retana J., Picó X., Direct regeneration is not the only response of Mediterranean forests to large fires, Ecology 85 (2004) $716-729$.

[42] Rundel P.W., Vegetation, nutrition and climate - examples of integration. 3. Leaf structure and nutrition in Mediterranean-climate sclerophylls, in: Specht R.L. (Ed.), Mediterranean-type ecosystems. A data source book, Kluwer Academic Publishers, Dordrecht, 1988, pp. 157-167.

[43] Terradas J., Holm oak and holm oak forests: an introduction, in: Rodà F., Retana J., Gracia C.A., Bellot J. (Eds.), Ecology of Mediterranean evergreen oak forests, Springer-Verlag, Berlin, 1999, pp. 3-14.

[44] Trabaud L., Dynamics after fire of sclerophyllous plant communities in the Mediterranean Basin. Ecologia Mediterranea, 13 (1987) $25-37$.

[45] Vilà M., Terradas J., Effects of competition and disturbance on the resprouting performance of the Mediterranean shrub Erica multiflora L. (Ericaceae), Am. J. Bot. 82 (1995) 1241-1248.

[46] Vilà M., Terradas J., Effects of nutrient availability and neighbours on shoot growth, resprouting and flowering of Erica multiflora, J. Veg. Sci. 6 (1995) 411-416.

[47] Vila B., Guibal F., Torre F., Martin J.L., Can we reconstruct deer browsing history and how? Lessons from Gaultheria shallon Pursh., Ann. For. Sci. 62 (2005) 153-162.

[48] Wilson A.D., Harrington G.N., Grazing ecology and animal production, in: Harrington G.N., Wilson A.D., Young M.D. (Eds.), Management of Australia's rangelands, CSIRO Publications, Collingwood Victoria, 1990, pp. 63-77. 